\title{
KONTAK BAHASA ANTARA MASYARAKAT \\ TUTUR BAHASA BAJO DAN MBOJO \\ DI KABUPATEN BIMA DAN DOMPU
}

\author{
Lalu Erwan Husnan*)
}

\begin{abstract}
Abstrak
Kontak bahasa antara masyarakat tutur bahasa Bajo dan masyarakat tutur bahasa Mbojo di Kabupaten Bima dan Dompu dilakukan karena alasan yang berbeda-beda. Kontak bahasa mengakibatkan terjadinya adopsi ciri-ciri kebahasaan, adaptasi linguistik, mitra kontak dalam bentuk serapan bahasa. Serapan bahasa terjadi pada tataran fonologi, leksikon, dan morfologi. Wujud adaptasi dalam bentuk serapan dilakukan dengan cara mengikuti sistem bahasa mitra kontak. Penutur bahasa Bajo melakukan serapan sebagai wujud adaptasi sosial mereka, berbeda dengan penutur bahasa Mbojo yang melakukan serapan sebagai wujud solidaritas mereka.
\end{abstract}

Kata kunci: kontak bahasa, adopsi, adaptasi linguistik, dan mitra kontak

\section{Pendahuluan}

Bahasa Bajo adalah satu diantara sekian bahasa dengan jumlah penutur tidak terlalu banyak (minoritas) di Nusa Tenggara Barat yang masih tumbuh dan tetap dipertahankan oleh penuturnya (etnis Bajo). Masyarakat Bajo adalah masyarakat multilingual karena mereka mempertahankan bahasa Bajo sekaligus mampu berkomunikasi, baik pasif maupun aktif, dengan penutur bahasa lain di tempat mereka berada. Fenomena ini dapat dimengerti karena masyarakat penutur bahasa minoritas, untuk kepentingan komunikasi lintas budaya dan untuk tujuan tertentu, mampu berkomunikasi dengan etnis yang mendominasi suatu

\footnotetext{
*) Sarjana Pendidikan, Pembantu Pimpinan pada Kantor Bahasa Prov. NTB
} 
wilayah tempat mereka tinggal atau bermukim (Syarifuddin, 2006:33), Samawa (Kasman, 2006), dan Sasak (Yudiastini, 2006:5 dan Husnan, 2003:6).

Fenomena multilingual masyarakat penutur bahasa Bajo di Bima tidak bisa lepas dari pengaruh faktor sosial, seperti faktor ekonomi, faktor pendidikan, dan faktor identifikasi sosial. Untuk itu, penutur bahasa Bajo memiliki strategi khusus dalam hal memilih kode (bahasa) dalam berkomunikasi dengan bahasa dan budaya yang berbeda. Salah satu wujud interaksi sosial mereka adalah dalam bentuk kontak bahasa. Kontak bahasa di sini adalah sebagai salah satu stratgei alternasi sosial. Kontak bahasa sendiri dilakukan dalam bentuk adaptasi linguistik. Adapun adaptasi linguistik merupakan proses adopsi ciri-ciri bahasa tertentu oleh penutur bahasa Bajo atau kedua-duanya (penutur bahasa Bajo dan Mbojo) melakukan hal yang sama (Mahsun, 2006:4). Dalam perjalanannya bahasa-bahasa tersebut mengalami perubahan dengan polanya sendiri (Bynon 1979 dalam Burhanuddin dkk., 2005). Perubahan tersebut tetap mewarisi unsur-unsur bahasa asalnya, baik unsur yang telah berubah atau tidak. Foley (1979 dalam Mahsun, 2005:8) mengatakan bahwa perubahan bahasa yang diakibatkan oleh kontak bahasa dua atau lebih komunitas yang berbeda merupakan hal yang alamiah. Proses adopsi tersebut dalam linguistik disebut konvergensi. Namun selain itu, perubahan dalam bentuk adopsi ciri-ciri kebahasaan bahasa tertentu bisa saja tidak berwujud konvergensi, tetapi berwujud divergensi, yaitu masyarakat tutur bahasa tertentu melakukan perubahan ciri-ciri kebahasaannya menjadi tidak sama dengan ciri-ciri bahasa yang digunakan oleh komunitas tutur lainnya yang menjadi mitra kontak. 
Adapun adaptasi linguistik dalam bentuk adaptasi ciri-ciri kebahasaan oleh suatu bahasa terhadap bahasa yang lain atau keduanya saling mengadopsi dapat berwujud:

1) penyesuaian kaidah/bunyi bahasa mitra bahasa dan

2) penggantian unsur bahasa pembicara dengan unsur bahasa mitra wicara dalam bentuk pinjaman (leksikon maupun gramatikal) (Foley, 1997 dalam Mahsun 2005:8).

Dengan memanfaatkan data adaptasi linguistik di atas, setelah dilakukan penghitungan kuantitatif sederhana berpatokan pada segmen sosial (tua dan muda), dapat diketahui segmen sosial mana dalam komuinitas tersebut yang lebih dominan melakukan adaptasi linguistik. Hal ini tidak lepas dari pengaruh faktor sosial, seperti faktor ekonomi, faktor pendidikan, dan faktor identifikasi sosial.

Untuk mengetahui apakah unsur kebahasaan itu merupakan unsur asli atau merupakan hasil adaptasi linguistik akan dilihat menggunakan prinsip-prinsip (Mahsun, 2005:352) sebagai berikut.

a. Menghubungkan bentuk-bentuk yang menjadi realisasi makna tertentu dalam kedua bahasa yang dihubungbandingkan dengan bentuk yang telah direkonstruksi bahasa purbanya. Apabila bentuk tersebut sama atau menyerupai (mirip) dengan bentuk purbanya, bentuk itu harus dipandang sebagai pewarisan bahasa purbanya dan bentuk asli bahasa tersebut. Sebaliknya, apabila bentuk tersebut tidak mirip dengan bentuk purbanya, tetapi mirip dengan bahasa yang digunakan mitra kontaknya, maka bentuk itu haruslah dipandang sebagai adaptasi linguistik.

b. Melihat distribusi penggunaan bentuk itu pada daerah lain yang menggunakan bahasa yang sama. Apabila bentuk tersebut juga 
dipakai daerah lain yang sama dengan bahasa tersebut, bentuk tersebut harus dipandang sebagai bentuk asli. Sebaliknya, jika bentuk tersebut distribusi pemakaiannya terbatas dan mirip/sama dengan yang dugunakan pada bahasa yang menjadi mitra kontaknya, bentuk tersebut harus dipandang sebagai hasil adaptasi linguistik.

c. Apabila dalam suatu bahasa menggunakan bentuk ganda dalam merealisasikan satu makna dan salah satu dari bentuk tersebut menyerupai/mirip/sama dengan bentuk bahasa mitra kontaknya, bentuk tersebut dianggap sebagai hasil adaptasi linguistik yang disebabkan faktor keeratan hubungan antara penutur kedua komunitas tutur bahasa yang berbeda.

2. Wujud Adaptasi

Wujud adaptasi sebagai akibat dari kontak bahasa antara masyarakat tutur bahasa Bajo dan masyarakat tutur bahasa Mbojo di Kabupaten Bima dan Dompu adalah adaptasi linguistik. Wujud adaptasi linguistik yang dimaksud adalah serapan yang terjadi pada tataran fonologi, leksikon, dan morfologi baik dari bahasa Mbojo, sebagai bahasa utama penduduk yang mendominasi kedua kabupaten tersebut, ke dalam bahasa Bajo ataupun dari bahasa Bajo, bahasa ibu salah satu masyarakat minoritas di kedua kabupaten tersebut, ke dalam bahasa Mbojo meskipun pada tataran segmentasi sosial adakalanya tidak terdapat bukti adaptasi.

Secara umum wujud adaptasi dalam bentuk serapan fonologi yang dilakukan masyarakat tutur bahasa Bajo dari bahasa Mbojo terjadi pada tataran vokalis (terbuka), konsonan tunggal pada posisi tengah, vokal [i] dan [a] pada posisi awal, dan konsonan dental hambat pada posisi awal. 
Pada dasarnya kedua bahasa bukan bahasa serumpun atau tidak masuk dalam satu kelompok/keluarga bahasa yang sama sehingga serapan yang terjadi tidak serta merta membuat hasil serapan (realisasi) mirip/berbeda dengan bahasa mitra kontaknya, melainkan yang terjadi adalah serapan dengan cara mengikuti sistem bahasa yang dimiliki mitra kontak. Serapan pertama (vokalis) dan kedua (konsonan tunggal) dilakukan hanya dengan melesapkan konsonan pada posisi ultima dan melesapkan salah satu anggota konsonan geminan pada posisi tengah.

Pada tataran leksikon, penutur bahasa Bajo melakukan serapan dengan mengganti konsonan dan mengambil dengan utuh leksikon bahasa Mbojo, sedangkan pada tataran morfologi samasekali tidak ditemukan bukti serapan baik dari bahasa Mbojo ke bahasa Bajo ataupun sebaliknya dari bahasa Bajo ke bahasa Mbojo. Kedua bahasa tersebut melakukan serapan morfologi dari bahasa Indonesia.

Kontak bahasa timbal balik (dua arah) mengakibatkan penutur bahasa Mbojo di Desa Bugis Kecamatan Sape dan Desa Soro Kecamatan Kempo juga melakukan serapan fonologi dan leksikon dari bahasa Bajo, sebagai bahasa mitra kontaknya meskipun persentasenya tidak terlalu mencolok. Serapan yang dilakukan penutur bahasa Mbojo bertentangan dengan sistem vokalis (terbuka) bahasa Mbojo karena yang diserap adalah sistem tertutup (konsonan) pada posisi ultima. Kebalikan dari cara penutur bahasa Bajo menyerap bahasa Mbojo, penutur bahasa Mbojo melakukan serapan dengan cara menambahkan konsonan pada posisi ultima. Hal yang sama juga terjadi pada serapan leksikon hanya terjadi penambahan konsonan pada posisi ultima, sedangkan pada tataran morfologi tidak ditemukan bukti serapan sama sekali. 
Masyarakat tutur bahasa Bajo dan Mbojo juga sama-sama melakukan serapan dari bahasa Indonesia. Serapan yang dilakukan dengan cara penyesuaian bunyi yang berakibat pada pelesapan dan penggantian huruf.

3. Segmen sosial yang lebih dominan, sedang, atau kurang dominan melakukan serapan

Setelah melalui proses analisis data mengikuti prinsip-prinsip penentuan apakah suatu bentuk realisasi merupakan bentuk asli atau adaptasi linguistik (serapan), diperoleh 366 bentuk realisasi yang dianggap sebagai serapan sebagai akibat dari kontak bahasa antara masyarakat tutur bahasa Bajo dan masyarakat tutur bahasa Mbojo serta pengaruh bahasa Indonesia terhadap kedua bahasa tersebut. Dengan menggunakan penghitungan statistik sederhana dapat diketahui segmen sosial mana yang lebih dominan, sedang, atau kurang dominan melakukan serapan bahasa.

Daerah Pengamatan (DP) Desa Bugis, Kecamatan Sape lebih dominan melakukan serapan. Persentase serapan di Desa Bugis mencapai 53\% (194 realisasi) dibandingkan dengan DP Desa Soro, Kecamatan Kempo dan DP Desa Bajo, Kecamatan Soromandi yang kurang dominan melakukan serapan. Persentase serapan kedua DP tersebut masingmasing adalah $25 \%$ dan $22 \%$.

Dari keseluruhan jumlah serapan di Desa Bugis, serapan dari bahasa Indonesia ke bahasa Bajo menduduki peringkat tertinggi (34\%) meskipun tidak dominan (sedang). Berikutnya disusul oleh serapan dari bahasa Bajo ke bahasa Mbojo (29\%), serapan dari bahasa Mbojo ke bahasa Bajo (26\%), dan serapan dari bahasa Indonesia (10\%). Ketigatiganya tergolong kurang dominan. Dari persentase serapan ini dapat 
diketahui bahwa di Desa Bugis terjadi serapan timbal balik antara kedua komunitar tutur bahasa yang berbeda. Hal ini dibuktikan dengan tidak adanya komunitas yang mendominasi serapan.

Di Desa Soro, Kecamatan Kempo serapan didominasi oleh serapan dari bahasa Mbojo ke bahasa Bajo (50\%), sedangkan serapan dari bahasa Indonesia ke bahasa Mbojo hanya 20\%, dari bahasa Bajo ke bahasa Mbojo 18\%, dan bahasa Indonesia ke bahasa Bajo 12\%. Di DP Soro, serapan lebih banyak dilakukan oleh komunitas tutur bahasa Bajo. Hal ini tidak lain karena bahasa Mbojo merupakan bahasa keseharian di DP tersebut. Bahasa Mbojo tidak hanya digunakan oleh penutur bahasa Mbojo itu sendiri, tetapi juga digunakan sebagai bahasa keseharian antara penutur bahasa Bajo dengan penutur bahasa Mbojo, penutur bahasa Bajo dengan penutur bahasa Bugis, dan penutur bahasa Mbojo dengan penutur bahasa Bugis.

Serapan di DP Desa Bajo, Kecamatan Soromandi juga didominasi oleh serapan dari bahasa Mbojo ke bahasa Bajo (51\%). Serapan dari bahasa Indonesia ke bahasa Bajo tergolong sedang (34\%), sedangkan serapan dari bahasa Indonesia ke bahasa Mbojo tergolong kurang (6\%), dan tidak ditemukan bukti serapan dari bahasa Bajo ke bahasa Mbojo. Hampir mirip dengan kondisi di DP Desa Soro, di DP Desa Bajo bahasa Bajo hanya digunakan oleh penutur tua saja karena bahasa keseharian di DP tersebut adalah bahasa Mbojo.

Serapan antara masyarakat tutur bahasa Bajo dan Mbojo di Bima dan Dompu didominasi oleh serapan pada tataran fonologi, yaitu mencapai $79 \%$. Lebih dari setengah serapan dilakukan oleh penutur tua. Pada tataran leksikon serapan hanya mencapai 16\%, sedangkan serapan pada tataran morfologi hanya 5\%. Perlu dicatat di sini bahwa pada 
tataran morfologi kedua masyarakat tutur bahasa sama sekali tidak melakukan serapan satu sama lainnya. Kedua masyarakat tutur menyerap unsur morfologi dari bahasa Indonesia .

Serapan timbal balik kedua penutur bahasa mencapai 211 realisasi. Serapan dari bahasa Mbojo ke bahasa Bajo lebih dominan (65\%), dibandingkan dengan serapan dari bahasa Bajo ke bahasa Mbojo 35\%. Serapan dari bahasa Mbojo ke bahasa Bajo didominasi oleh serapan fonologi $(94 \%)$, sedangkan serapan leksikon hanya $6 \%$. Hal yang sama juga terjadi pada serapan dari bahasa Bajo ke bahasa Mbojo, 95\% serapan didominasi oleh serapan fonologi, sedangkan serapan leksikon hanya $5 \%$.

Penutur bahasa Bajo, secara umum, lebih dominan melakukan serapan dari bahasa Indonesia sebanyak 72\%, dibandingkan dengan serapan penutur bahasa Mbojo dari bahasa Indonesia sebanyak 28\% (kurang dominan). Serapan fonologi juga mendominasi serapan kedua penutur bahasa dari bahasa Indonesia masing-masing 53\% oleh penutur bahasa Bajo dan $75 \%$ oleh penutur bahasa Mbojo. Serapan leksikon kedua penutur bahasa dari bahasa Indonesia tergolong sedang dan kurang masing-masing 34\% oleh penutur bahasa Bajo dan $21 \%$ oleh penutur bahasa Mbojo. Pada tataran morfologi penutur bahasa Bajo menyerap sekitar 14\% dari bahasa Indonesia dan penutur bahasa Mbojo menyerap $4 \%$.

Serapan dari bahasa Mbojo ke bahasa Bajo didominasi oleh serapan fonologi (94\%). Dari keseluruhan jumlah serapan fonologi tersebut, 75\% diantaranya dilakukan oleh penutur tua, sedangkan penutur muda hanya 19\%. Hampir sama dengan serapan dari bahasa Mbojo ke bahasa Bajo, serapan dari bahasa Bajo ke bahasa Mbojo didominasi oleh serapan 
fonologi, yaitu 95\%, berbeda dengan sebelumnya, serapan fonologi dari bahasa Bajo ke bahasa Mbojo didominasi oleh penutur penutur muda, yaitu $90 \%$, sedangkan penutur tua hanya $5 \%$.

Hal yang sama juga terjadi pada serapan yang dilakukan oleh kedua penutur bahasa dari bahasa Indonesia. Keduanya tetap didominasi oleh serapan fonologi. Komunitas tutur bahasa Bajo didominasi oleh penutur tua (40\%), sedangkan penutur bahasa Mbojo didominasi oleh penutur muda (66\%). Begitu juga dengan serapan pada tataran leksikon, penutur bahasa Bajo didominasi oleh penutur tua meskipun hanya 31\%, dan penutur bahasa Mbojo didominasi oleh penutur muda, yaitu 23\%. Pada tataran morfologi juga terjadi hal yang sama, komunitas tutur bahasa Bajo didominasi oleh penutur tua $(12 \%)$ dan komunitas tutur bahasa Mbojo didominasi oleh penutur muda (4\%).

4. Faktor penyebab

Seperti telah dipaparkan sebelumnya, komunitas tutur bahasa Bajo adalah masyarakat minoritas di Kabupaten Bima dan Kabupaten Dompu. Sebagai masyarakat minoritas etnis Bajo melakukan komunikasi dengan masyarakat yang mendominasi, Mbojo, (kontak bahasa) dan masyarakat tutur lainnya yang ada di sekitar tempat mereka bermukim. Sebagai akibat dari kontak bahasa tersebut terjadi proses adaptasi linguistik. Wujud adaptasi tersebut adalah serapan bahasa. Adaptasi linguistik dalam bentuk serapan bahasa tidak terjadi begitu saja, tetapi dipengaruhi oleh banyak faktor diantaranya faktor interaksi sosial dan kepuasan hati para penuturnya.

Sebagai masyarakat minoritas, etnis Bajo harus berinteraksi dengan masyarakat Mbojo untuk memenuhi kebutuhan ekonomi, perdagangan, pendidikan, dan kebutuhan sosial lainnya. Untuk alasan tersebut 
kelompok etnis Bajo harus mengetahui bahkan dapat berkomunikasi dalam bahasa Mbojo. Hal ini dibuktikan dengan fakta bahwa baik penutur tua ataupun muda dapat berkomunikasi dalam bahasa Mbojo. Trudgill (1983 dalam Husnan, 2003:38) mengatakan bahwa bahasa dapat digunakan sebagai sarana memperkuat hubungan sosial dan untuk mendapatkan tujuan sosial lainnya. Fakta lapangan juga menunjukkan bahwa bahasa sehari-hari di ketiga DP adalah bahasa Mbojo. Dengan kata lain, bahasa Mbojo tidak hanya digunakan oleh etnis Mbojo, tetapi juga digunakan oleh etnis lain di ketiga DP sebagai bahasa lintas budaya dan bahasa sehari-hari. Tiap-tiap komunitas tutur bahasa secara tidak langsung saling mengenal bahasa mitra kontak (dua arah) meskipun etnis minoritas lebih dominan, tetapi pemahaman timbal balik tetap terjadi.

Interaksi sosial dua arah dalam bentuk kontak bahasa yang mengakibatkan terjadinya serapan bahasa juga dipengaruhi oleh faktor kepuasan hati penutur bahasa terhadap bahasanya sendiri dan bahasa mitra kontaknya. Penutur bahasa Bajo melakukan kontak bahasa dalam bentuk serapan untuk memenuhi kebutuhan sosial mereka. Dengan demikian, mereka merasa senang dapat berkomunikasi dengan penutur bahasa Mbojo menggunakan bahasa Mbojo. Berbeda dengan penutur bahasa Bajo, penutur bahasa Mbojo melakukan kontak bahasa dengan penutur bahasa Bajo mengakibatkan serapan bahasa, sebagai wujud solidaritas sosial terhadap mitra kontaknya sehinggga tidak mengherankan jika persentase serapan dari bahasa Bajo ke bahasa Mbojo sedikit (kurang) bahkan pada beberapa tataran segmen sosial tidak terdapat bukti serapan.

5. Penutup 
Berdasarkan uraian di atas, dapat disimpulkan bahwa wujud adaptasi linguistik sebagai akibat dari kontak bahasa kedua komunitas tutur adalah dalam bentuk serapan fonologi, leksikon, dan morfologi. Total keseluruhan serapan yang diperoleh setelah melalui proses analisis adalah 366 realisasi.

Dari total keseluruhan serapan yang terkumpul, serapan fonologi paling mendominasi (79\%), didandingkan dengan serapan leksikon (16\%) dan serapan morfologi (5\%). Kedua komunitas tutur sama-sama melakukan serapan (timbal balik) dengan cara yang berbeda baik pada tataran fonologi, leksikon, ataupun morfologi.

Komunitas tutur bahasa Bajo di ketiga DP melakukan serapan fonologi dari bahasa Mbojo dengan cara mengikuti sistem vokalis bahasa Mbojo, menyerap konsonan tunggal pada posisi tengah, menyerap vokal [i] dan [a] pada posisi awal, dan menyerap konsonan dental hambat pada posisi awal. Serapan sistem vokalis dilakukan dengan cara melesapkan konsonan pada posisi ultima sehingga bentuk realisasi menjadi terbuka. Hal yang sama juga terjadi pada serapan konsonan tunggal, yaitu dengan cara melesapkan salah satu anggota konsonan geminan pada posisi awal. Dua wujud serapan berikutnya dilakukan dengan cara melakukan penyesuaian bunyi pada posisi awal.

Di lain pihak, penutur bahasa Mbojo melakukan serapan dengan cara substitusi (menambahkan) konsonan pada posisi ultima sehingga bentuk realisasi menjadi tertutup. Serapan tersebut adalah penambahan konsonan glotal letupan /q/, dental letupan /t/, alveolar nasal /n/, nasal sengau /y/ pada posisi ultima. Serapan ini terjadi di DP Desa Bugis dan Desa Soro, sedangkan di DP Desa Bajo tidak ditemukan bukti serapan dari bahasa Bajo ke bahasa Mbojo. Kedua masyarakat tutur juga sama- 
sama mendapat pengaruh dari bahasa Indonesia (Melayu). Kedua Masyarakat tutur melakukan serapan dari bahasa Indonesia (Melayu) pada tataran fonologi, leksikon, dan morfologi.

Dominasi penutur bahasa Bajo dalam melakukan serapan tidak lain karena dipengaruhi oleh faktor interaksi sosial. Penutur bahasa Bajo berkomunikasi atau melakukan kontak bahasa dengan penduduk asli (mayoritas) untuk memenuhi kebutuhan sosial mereka. Sementara itu, penutur bahasa Mbojo melakukan serapan dari bahasa Mbojo karena faktor solidaritas sosial sehingga terjadi kontak bahasa timbal balik (dua arah). Namun begitu, persentase serapan yang dilakukan komunitas tutur tertentu tergantung pada kepuasan hati mereka terhadap bahasanya sendiri dan bahasa mitra kontak. 


\section{DAFTAR PUSTAKA}

Burhanuddin, dkk., 2005. 'Kontak Bahasa Antara Bahasa Sumbawa di Lombok dengan Bahasa Sasak'. Laporan Penelitian Kelompok: Kantor Bahasa NTB.

Candrawati, dkk., 1997. Struktur Bahasa Bajo. Pusat Pembinaan dan Pengembangan Bahasa. Departemen Pendidikan dan Kebudayaan RI. Jakarta.

Dempwolff, Otto.1938. Austronesisches Wörterverzeichnis. Dietrich Reiner (Andrews \& Steiner) Berlin Hamburg: Friederichsen, De Gruyter \& Co.

Departemen Pendidikan Nasional. 2005. Kamus Besar Bahasa Indonesia. Edisi 3, cet. 4. Balai Pustaka.

Hapip, Abdul Djebar, dkk.1979. Bahasa Bajau. Pusat Pembinaan dan Pengembangan Bahasa. Departemen Pendidikan dan Kebudayaan. Jakarta.

Husnan, L.Erwan, 2003. 'Codeswithcing in Bajo Language: a Case Study in Maringkik Island East Lombok'. Skripsi S1 FKIP Universitas Mataram.

Hymes, Dell, 1979. Foundation in Sociolinguistics: an Ethnographic Approach. USA: The University of Pennysylvania Inc.

Ismail, Mansyur, dkk. 1985. Kamus Bima-Indonesia. Pusat Pembinaan dan Pengembangan Bahasa. Departemen Pendidikan dan Kebudayaan. Jakarta.

Kadir, Mohd. Daud, dkk., 1986. Dialek Bahasa Orang laut. Pusat Pembinaan dan Pengembangan Bahasa Departemen Pendidikan dan Kebudayaan. Jakarta.

Kasman, 2006. 'Distribusi dan Pemetaan Bahasa Bajo di Kabupaten Sumbawa dan Sumbawa Barat; Suatu Kajian Dialektologi'. Laporan Penelitian Kantor Bahasa NTB. 
Mahsun, 1995. Dialektologi Diakronis: Sebuah Pengantar. Yogyakarta: Gadjah Mada University Press.

, 2005. Metode Penelitian Bahasa: Tahapan Strategi, Metode, dan Tekniknya. Jakarta: PT Rajagrafindo Peresada.

, 2006. Kajian Dialektologi Diakronis bahasa Mbojo di Bima dan Dompu. Yogyakarta: Gama Media.

, 2006. Bahasa dan Relasi Sosial: Telaah Kesepadanan Adaptasi Linguistik dengan Adaptasi Sosial. Yogyakarta: Gama Media.

Ranabrata, Utjen Djusen. 1991. Refleks Fonem Proto-Austronesia Bahasa Sunda. Departemen Pendidikan dan Kebudayaan.

Syarifuddin, 2006. 'Distribusi dan Pemetaan Varian-varian Bahasa Bajo di Kabupaten Bima dan Dompu'. Laporan Penelitian: Kantor Bahasa NTB.

Tarigan, Henry Guntur. 1985. Pengajaran Morfologi. Angkasa Pura: Bandung.

Yudiastini, Ni Made, 2006. 'Distribusi dan Pemetaan Varian Bahasa Bajo di Pulau Lombok'. Laporan Penelitian: Kantor Bahasa NTB. 